\section{Cadmium quantification in Brazilian mothers colostrum: a regional study}

\section{Quantificação de cádmio em colostro de mães brasileiras: um estudo regional}

Luiz Fernando C. Nascimento 1

Hélcio José Izário Filho 2

Mariana Luz Pereira 3

Nivaldo Baccan 4

1 Departamento de Medicina. Universidade de Taubaté Av. Tiradentes, 500. Taubaté, SP, Brasil. CEP: 12.080-130. E-mail:1fcn@unitau.br

2,3 Faculdade de Engenharia Química de Lorena, SP, Brasil

4 Instituto de Química. Universidade de Campinas, SP. Brasil.

\section{Resumo}

Objetivos: estimar a quantidade de cádmio em colostro de mães de Taubaté.

Métodos: foi realizado um estudo do tipo trans versal envolvendo mães que deram à luz no Hospital Universitário de Taubaté, no ano de 2003. O colostro foi coletado até um dia após o parto, em tubos de polipropileno previamente tratados e refrigerado a$20^{\circ} \mathrm{C}$. As variáveis independentes foram idade materna, peso do recém-nascido, idade gestacional, paridade, hábitos alimentares, relato de fumo e ocupação materna. Cádmio foi quantificado através da técnica da espectroscopia de absorção atômica. Foram utilizados a técnica não-paramétrica de Mann-Whitney para comparação das médias e a correlação de Pearson para verificar associações. $O$ nivel de significância adotado foi alfa $=5 \%$.

Resultados: o valor médio de cádmio encontrado foi $54,5 \mathrm{mg} / \mathrm{L}(\mathrm{dp}=381,0 \mathrm{mg} / \mathrm{L})$, sendo quantificado em 18 de 58 amostras $(31,0 \%)$. Não foram observadas correlações nem diferenças entre o conteúdo de cádmio e as variáveis estudadas.

Conclusões: os valores encontrados neste estudo estão acima dos encontrados por outros autores e é importante identificar as possiveis fontes deste conta minante no ambiente materno.

Palavras-chave Cadmio, Colostro, Análise espec tral, Absorção atômica, Leite humano, Metais pesados 


\section{Introduction}

Human milk is the best way of feeding the newborn, recommended as the exclusive way of feeding up to six months of life, and can be maintained along the first two years of life, followed by supporting nutritious. It contains necessary nutrients to the appropriate newborn growth; it also contains essential metals as iron, copper, manganese and zinc. Besides these components, human milk and the colostrum can transport heavy and toxic metals, like cadmium.

The cadmium $(\mathrm{Cd})$ is a heavy metal that can be found in the proximities of industrial cities and as environmental pollutant in the air, in food and in water, and also in tobacco.1,2 Increases in soil cadmium content results in an increase in the uptake of cadmium by plants; the pathway of human exposure from agricultural crops is thus susceptible to increases in soil cadmium. The uptake by plants from soil is greater at low soil $\mathrm{pH}$. Processes that acidify soil (e.g., acid rain) may therefore increase the average of cadmium concentration in foodstuffs. ${ }^{3}$

The effects of the cadmium in the human body can be reflected in the kidneys, lungs, bones and nervous system.4,5 High inhalation exposure to cadmium oxide fume results in acute pneumonitis with pulmonary oedema, which may be lethal. High ingestion exposure of soluble cadmium salts causes acute gastroenteritis. Long-term occupational exposure to cadmium has caused severe chronic effects, predominantly in the lungs and kidneys. Chronic renal effects have also been seen among the general population. Following high occupational exposure, lung changes are primarily characterized by chronic obstructive airway disease. Early minor changes in ventilatory function tests may progress, with continued cadmium exposure, to respiratory insufficiency. An increased mortality rate from obstructive lung disease has been seen in workers with high exposure, as has occurred in the past. Chronic exposure to a low dose of cadmium may also cause hypertension and infertility in male rats.3,6

The mean blood concentration of cadmium was higher in mothers who were delivered of preterm infants. ${ }^{7}$ Cadmium is known to accumulate in the placenta, and the mothers exposed to cadmium through smoking habits, which increase placental cadmium concentration, were shown to have children with lower birthweight. 8

The entrance of cadmium in the newborn organism is through colostrum and maternal milk. In a study with 57 mothers, Nishijo et al. 7 found correlation between levels of cadmium in the maternal blood and in the maternal milk, showing a possible maternal-fetal transfer by human milk. Higher level of blood cadmium was associated with older maternal age but no correlation between parity and blood cadmium was detected. 7

Tobacco is a possible source to increase the level of maternal cadmium, and the association between tobacco and its concentration in the maternal milk was studied by Radish et al. ${ }^{9}$ However, Turan et al. 10 in Turkey, in a sample with 30 mothers, found the mean of cadmium concentration of $2.8 \mu \mathrm{g} / \mathrm{L}$, varying between $1.2 \mu \mathrm{g} / \mathrm{L}$ and $9.0 \mu \mathrm{g} / \mathrm{L}$, without association with report of tobacco, and Krachler et al. ${ }^{11}$ in Slovenia, found the mean value of $0.60 \mu \mathrm{g} / \mathrm{L}$, varying between $0.18 \mu \mathrm{g} / \mathrm{L}$ and $1.90 \mu \mathrm{g} / \mathrm{L}$.

Usually, the studies about cadmium concentration in human milk, do not consider maternal variables, just possible exposure as environmental pollutants.

There are not studies quantifying this heavy metal in the human colostrum in Brazil. So, the objective of this paper is to estimate the values of cadmium in the human colostrum of Brazilian mothers.

\section{Methods}

It is a cross-sectional study, involving mothers that were delivered in the University Hospital of Taubaté, São Paulo, Brazil, a tertiary attendance regional center, between September and November 2003. Taubaté lays between São Paulo and Rio de Janeiro cities, and it has an important industrial area; its population is near 250.000 inhabitants.

The inclusion rule was mother with normal pregnancy, a healthy newborn and easiness to give a colostrum sample. The mothers that participated in this study had the prenatal attendance in the University Hospital. They are users of the Public System of Health and they did not present diseases during the gestation that was taken to term. The mother sampling was the cumulative type in according with other studies. 10-12

The samples containing $5 \mathrm{ml}$ of colostrum were collected in the hospital, in the first 24 hours postpartum; the colostrum was obtained by manual expression of the breast, after being cleaned with deionized water, and it was conditioned in polypropylene tubes previously prepared with nitric acid $10 \% \mathrm{v} / \mathrm{v}$, and soon afterwards, stored at $-20{ }^{\circ} \mathrm{C}$. The collection was after the newborn sucking. Just one expert in pediatrician collected the samples.

The graphite furnace atomic absorption spectrometry with Zeeman-effect background correction was used to determine the content of cadmium, 
being used the Perkin Elmer spectrometer, model A analyst 800 .

The samples, in duplicate, were digested in Teflon capsules, using an acid mixture of $\mathrm{HCl}$ and $\mathrm{HNO}_{3}$. The Teflon capsules were introduced in capsules of aluminum, resistant to pressure and temperature, where it was heated up in resistive oven of stainless steel with temperature control.

For the method accuracy, an assured material of powdered milk was used, distributed by the National Institute of Standard and Technology, RM 8435 , tends a high recovery $(>95 \%)$ with a $2.0 \%$ relative standard deviation.

In this study, in case the values found for cadmium were below the quantification limit (LOQ), these were considered zero.

The independent variables were: maternal age obtained in years old, maternal tobacco history, parity, birthweight, gestational age, dietary habits and maternal occupation.

The maternal age was classified in adolescent, up to 19 years old, and adult, the others; the parity was classified for the first time deliveries in primiparous and the others were considered multiparous. The birthweight was obtained in grams and the gestation age was estimated in days. The dietary habits were collected in according to a questionnaire; the questions on diet included consumption of bean, rice, beef, fish, poultry, local-grown vegetables, pasteurized milk, coffee, bread, butter and wine consumption, in the previous two months period. The informations about dietary habits, maternal tobacco history and maternal occupation were obtained by interview with the mothers. The data relative to newborns were collected through medical records. Two classes were created for the quantification of cadmium; the first class with mothers whose colostrum did not contain enough cadmium to be quantified, and another class with mothers whose colostrum contained quantifiable cadmium.

The correlation was done between the continuous variables and the amount of cadmium, being used the Pearson correlation. The means were compared by the Mann-Whitney U-test . The significance level adopted in this study was alpha $=5 \%$.

All mothers included in this study were residents in the urban area of Taubaté and they agreed to their inclusion in this study after the explanation of the research subject. The Committee of Ethics of the University Hospital of Taubaté approved this study.

\section{Results}

The cadmium LOQ was $0.13 \mu \mathrm{g} / \mathrm{L}$, and it was detected in 18 samples of human colostrum (31.0\%) (CI 95\%: 19.5\%-44.5\%); when present, their values oscillated between $0.13 \mu \mathrm{g} / \mathrm{L}$ and $2904.0 \mu \mathrm{g} / \mathrm{L}$. Considering the values below the quantification limit as zero, the mean value found for the cadmium was $54.5 \mu \mathrm{g} / \mathrm{L}(\mathrm{SD}=381.0 \mu \mathrm{g} / \mathrm{L})$.

There were studied 58 samples of human colostrum. The values of variables are in Table 1 . There was a positive tobacco history in seven mothers and negative in 51 .

All mothers did not work in the trade or in the industry of the city or area. In relation to mothers dietary, the questionnaire showed there was not report of routine consumption of wine or distilled and also of fish; the alimentary habits were restricted to rice, bean, beef, poultry, local-grown vegetables, pasteurized milk, butter, coffee and bread. It is important to point that these foods are the most common used by the inhabitants of this region.

Table 1

Means values, standard deviation and interval amplitud of maternal and newborn variables. Taubaté, São Paulo, 2003.

\begin{tabular}{lcc}
\hline & $\overline{\mathbf{X}} \pm \mathrm{sd}$ & Min - Max \\
\hline Maternal age (years old) & $25.0 \pm 7.0$ & $15-45$ \\
Birthweight (g) & $3033.1 \pm 479.2$ & $2165-4250$ \\
Gestational age (days) & $270.1 \pm 8.7$ & $246-288$ \\
Parity (children) & $1.4 \pm 1.6$ & $1-7$ \\
\hline
\end{tabular}

Table 2 shows the mean values, respective standard deviation and $\mathrm{p}$, to the birthweight, gestational age, maternal age, and parity in according to the situation of cadmium quantification, yes or no, in the colostrum.

There was a positive correlation between maternal age and cadmium level $(\mathrm{r}=0.16)$ and a negative correlation between parity and cadmium level $(\mathrm{r}=-0.05)$; both values howerver had not statistical significance. ( $p=0,25$ and 0,80 respectively). 
Mean values, standard deviation and $\mathrm{p}$ value of birthweight, gestational age, maternal age, parity and body mass index (BMI) in according with cadmium (Cd) quantification yes or not. Taubaté, São Paulo, 2003.

\begin{tabular}{lccc}
\hline & $\begin{array}{c}\text { Cd quantified } \\
\overline{\mathbf{X}} \pm \mathrm{sd}\end{array}$ & $\begin{array}{c}\text { Cd not quantified } \\
\overline{\mathbf{X}} \pm \mathrm{sd}\end{array}$ & $\boldsymbol{p}^{\#}$ \\
\hline Birthweight (g) & $2998.7 \pm 615.2$ & $3047 \pm 421.2$ & 0.50 \\
Gestational age (days) & $268.9 \pm 10.6$ & $270.6 \pm 7.9$ & 0.68 \\
Maternal age (years old) & $26.4 \pm 6.6$ & $24.4 \pm 7.1$ & 0.29 \\
Parity (children) & $1.53 \pm 1.92$ & $1.35 \pm 1.41$ & 0.96 \\
\hline
\end{tabular}

\# Mann-Whitney U-test

Table 3 shows the values found in this study and those found in other mentioned papers. It can be seen that the values here presented are especially above those found in other countries and the number of mothers enrolled in our study is similar to the other studies. The analysis performed to cadmium quantification in these studies was the graphite furnace atomic absorption spectrometry technique.

There were not differences among the medium contents of Cd ( $7 \mu \mathrm{g} / \mathrm{L}$ x $305 \mu \mathrm{g} / \mathrm{L}, \mathrm{p}=0.16)$ between the primiparous and multiparous mothers.

As for the tobacco report, there were not found differences with statistical significance among the contents of $\mathrm{Cd}$ in the smoking mothers colostrum when compared with no smokers mothers. The values found for the cadmium, there was just one smoking mother with a quantified value equal to 2.1 $\mu \mathrm{g} / \mathrm{L}$ and 17 no smokers mothers who presented the mean value of $184 \mu \mathrm{g} / \mathrm{L}$.

Table 3

Cadmium mean values, in $\mathrm{mg} / \mathrm{L}$, related in University Hospital of Taubaté, São Paulo, study and in other studies, according to human milk under analysis.

\begin{tabular}{lc}
\hline & $\mathbf{C d}$ \\
& $\overline{\mathbf{X}}$ \\
\hline Hallén et al. 15 [mature milk] (73) \# & 0.28 \\
Krachler et al. ${ }^{11}$ [colostrum] (30) & 0.60 \\
Tripathi et al. 12 [mature milk] (30) & 0.09 \\
Turan et al. 10 [colostrum] (30) & 2.80 \\
University Hospital of Taubaté (SP) & \\
(2004) [colostrum] (58) & 54.50 \\
\hline
\end{tabular}

\# In brackets the number of mothers in each study.

\section{Discussion}

It is the first study about cadmium content in the human colostrum in Brazil. There are also few papers involving heavy metals in the human milk, in the world literature. The sampling size of this study was larger than others. ${ }^{10-12}$

The authors, except Nishijo et al.,7 usually do not consider maternal or newborn variables. This study included maternal variables as age and parity and newborn variables as birthweight and gestational age in an attempt to find any association of cadmium contents in human colostrum.

A positive correlation found between maternal age and colostrum cadmium level may explicated by the most continued contact among mother and this environment pollutant. It was not possible to find an acceptable explanation in respect to parity role in colostrum cadmium level.

The values of cadmium found in this study are above those observed in other studies. 1,7,9,12

Human beings are exposed to cadmium as a result of its ingestion of foods, beverages, or water, with a major contribution coming from food containing this metal. Because cadmium is a trace contaminant in many phosphate fertilizers, its presence in food supplies grown in the presence of such fertilizers is common. In respect to dietary habits, the foods studied are the most common used in our region but they were not quantified the daily ingestion of each one. Drinking water is another possible source of cadmium.13 Another way of cadmium contamination is through environmental pollutant such as in cigarette smoke; smoking one or more packs of cigarettes a day may double the body burden of cadmium. 
Considering that the colostrum ingestion by a newborn can be around of $600 \mathrm{ml} /$ day, with the mean values obtained in this study, it may be considered a mean ingestion of $\mathrm{Cd}$ around $33 \mu \mathrm{g} / \mathrm{day}$. Considering a 3-kg mean birthweight, these newborn ones would be ingesting $11 \mu \mathrm{g} / \mathrm{kg}$.day of cadmium, on average. These values are very higher than the acceptable ones that are $0.8-1.0 \mu \mathrm{g} / \mathrm{kg}$.day for the cadmium. 14 The values found by Hallén et al., 15 in the sixth postpartum week, were $0.07 \mathrm{mg} / \mathrm{L}$ for smoking mothers and $0.06 \mu \mathrm{g} / \mathrm{L}$ for non smoking mothers, not having difference with statistical significance. In this study there were not found differences either, but there was only one smoking mother with cadmium values quantified.

In this study there were not found differences in relation to the parity and maternal age coinciding with the finding of Honda et al. ${ }^{16}$ It was not also possible to identify differences between the mean values of the birthweight and the gestational ages according to the quantification or not of cadmium in the maternal colostrum.

It was not possible to find an explanation for the finding of cadmium higher values in colostrum of mothers who did not pass by industries, nor residents near metallurgies or foundries such as explained by Larsson et al. ${ }^{1}$ The contamination consists of inadvertent sources where the metal is a natural constituent of the material being processed or consumed. Sources associated with the disposal of materials that had earlier received cadmium discharges or discarded cadmium products make up the other category.

Thus, this first study accomplished in Brazil, although a regional study, shows the presence of cadmium in the human colostrum and that these values are much higher those found in other countries.

It also opens perspectives to identify possible environmental sources that contains this metal that should be controlled.

\section{Acknowledgements}

The authors are grateful to Francine S. Agostinho, $\mathrm{MD}$, whom collected the colostrum samples.

Biol Trace Elem Res 1991; 31: 209-14.

7. Nishijo M, Nakagawa H, Honda R, Tanebe K, Saito S, Teranishi H, Tawwara K. Effects of maternal exposure to cadmium on pregnancy outcome and breast milk. Occup Environ Med 2002; 59: 394-7.

8. Salpietro CD, Gangemi S, Minciullo PL, Briuglia S, Merlino MV, Steliano A. Cadmium concentration in maternal cord blood and infant birth weight: a study on healthy non-smoking women. J Perinat Med 2002; 30: 39599

9. Radish B, Werner L, Nau H. Cadmium concentration in milk and blood of smoking mothers. Toxicol Let 1987; 36: 147-52.

10. Turan S, Saygi S, Ktliç Z, Acar O. Determination of heavy metal contents in human colostrum samples by electrothermal atomic absorption spectrophotometry. J Trop Pediatr 2001; 47: 81-5. 
11. Krachler M, Rossipal E, Micetic-Turk D. Trace element transfer from the mother to the newborn - investigations on triplets of colostru m, maternal and umbilical cord sera. Eur J Clin Nutr 1999; 53: 486-94

12. Tripathi RM, Raghunath R, Sastry VN, Krishnamoorthy TM. Daily intake of heavy metals by infants through milk and milk products. Sci Total Environ 1999; 227: 229-35.

13. Calabrese EJ, Canada AT, Sacco C. Trace elements and public health. Ann Rev Public Health 1985; 6:131-46.

14. WHO (World Health Organiz ation), IAEA. Minor and trace elements in breast milk, Collaborative Study, World Health O rganization. Geneve; 1989.

15. Hallén IP, Jorhem L, Lagerkvist BJ, Oskarsson A. Lead and cadmium levels in human milk and blood. Sci Total Environ 1995; 166: 149- 55

16. Honda R, Tawara K, Nishijo M, Nakagawa H, Tanebe K, Saito S. Cadmium exposure and trace elements in human breast milk. Toxicology 2003; 186: 255- 9 .

Recebido em 29 de novem bro de 2004

Versão final apresentada em 11 de abril de 2005

Aprovado em 28 de abril de 2005 